\title{
The Proof for a Necessary Existent in the Summa Halensis
}

\begin{abstract}
Since the late medieval period, Anselm of Canterbury has been heralded in the West as the first proponent of the so-called ontological argument for God's existence. This kind of argument purports to provide proof for the reality of God, which is derived from the very definition of God as the supreme being. Although Anselm's work has garnered considerable attention in the late medieval and modern periods, it was largely neglected in the century between his death and the first years of the University of Paris in the early 13th century. A few other precedents notwithstanding, Alexander of Hales and the authors of the Summa Halensis were the first extensively to appropriate and popularise the work of Anselm, not least, the famous argument which can be found in chapters 2-3 of his Proslogion. As I will demonstrate in this chapter, however, the Summa's version of Anselm's argument represents a significant development beyond Anselm's own iteration. Through an assessment of Anselm's argument on its own terms and a study of the Summa's presentation of the argument in relation to its sources-above all, Richard of St Victor and AvicennaI will argue that early Franciscans rather than Anselm are responsible for developing the version of the ontological argument that has been associated in some form with Anselm's legacy to this day.
\end{abstract}

Since the late medieval period, Anselm of Canterbury has been heralded in the West as the first proponent of the so-called ontological argument for God's existence. This kind of argument purports to provide proof for the reality of God, which is derived from the very definition of God as the supreme being. As such a being, ontological arguments presume, God must possess all perfections-including the perfection of existence. Thus, one need only think about what he is to know that he exists. In that sense, ontological arguments are purely rational: they have no other source than human reason. Over the centuries, philosophers have formulated many different versions of this basic argument; however, most of them are framed with reference to a broader tradition of thought that supposedly began with Anselm. ${ }^{1}$

\footnotetext{
1 A version of this paper appears in Lydia Schumacher, Early Franciscan Theology: Between Authority and Innovation (Cambridge: Cambridge University Press, 2019). Variations on an ontological argument have been offered by Norman Malcolm, 'Anselm's Ontological Arguments,' The Philosophical Review 69 (1960): 41-62; Graham Oppy, Ontological Arguments and Belief in God (New York: Cambridge University Press, 1995); Alvin Plantinga, God and Other Minds (Ithaca: Cornell University Press, 1967); Alvin Plantinga, The Nature of Necessity (Oxford: Oxford University Press, 1974); Charles Hartshorne, Anselm's Discovery: A Re-Examination of the Ontological Proof for God's Existence (La Salle, IL: Open Court, 1965); Rene Descartes, 'Meditation 5,' in Discourse on Method and The Meditations, trans. F.E. 
Although Anselm's work has garnered considerable attention in the late medieval and modern periods, it was largely neglected in the century between his death and the beginnings of the University of Paris in the early $13^{\text {th }}$ century. A few other precedents notwithstanding, Alexander of Hales and the authors of the Summa Halensis were the first extensively to appropriate and popularise the work of Anselm, not least, the famous argument which can be found in Chapters 2 to 3 of his Proslogion. In writings completed both before and during the period of the Summa's authorship between 1236 and 1245, these first Franciscan intellectuals developed a common approach to reading Anselm's argument which is expressed most fully in the Summa itself. ${ }^{2}$ As this suggests, early Franciscans functioned 'as a community, and not merely as a group of scholars who happened to be working at the same institution.'

In this case as in so many others, moreover, the Summa Halensis stands as the clearest expression of their collective mind. When articulating their uniquely Franciscan perspectives, we have learned that the Halensian Summists tended to quote authorities not merely as a matter of unequivocal endorsement but with a view to locating their own opinions within larger traditions or streams of thought which could legitimize them. The example of the Summa's appropriation of Anselm's argument is no exception to this rule. As I will demonstrate in this chapter, the Summa's version of Anselm's argument represents a significant development beyond Anselm's own iteration. ${ }^{4}$ In order to bolster this claim, I will start by examining Anselm's argument, attending carefully to the pastoral or pedagogical objectives he outlines in his 26-chapter Proslogion. This discussion will cast doubt on the claim that the famous argument can be interpreted in exclusively ontological terms.

Following this, I will analyse the sources in addition to Anselm that inform the Franciscan interpretation of his argument. These sources include Avicenna, whose celebrated proof for the necessary existent is the closest forerunner of which I am aware for what is known today as the ontological argument. As a perceived associate of the Augustinian tradition, Anselm was not immune to an Avicennian interpretation. This interpretation became possible through the mediation of the $12^{\text {th }}$-century mystical theologian Richard of St Victor, who was perhaps the first to assess Anselm's argument without reference to the broader context of the Proslogion.

Sutcliffe (Harmondsworth: Penguin, 1968), 85-9; Gottfried Leibniz, New Essay Concerning Human Understanding, trans. Alfred Gideon Langley (New York: Macmillan, 1896).

2 Scott Matthews, Reason, Community, and Religious Tradition: Anselm's Argument and the Friars (Aldershot: Ashgate, 2001), 46-80, esp. 62.

3 Matthews, Reason, Community, and Religious Tradition, 72.

4 In his own way, Jean Chatillon has demonstrated this in his 'De Guillaume d'Auxerre à saint Thomas d'Aquin: l'argument de saint Anselme chez les premiers scolastiques duxième siècle,' in Spicilegium Beccense I: Congrès international du IXe centenaire de l'arrivée d'Anselme au Bec (Paris: Vrin, 1959), 209-31, esp. 226 - 7. See also Anton Pegis, 'The Bonaventurian Way to God,' Mediaeval Studies 29 (1967): $206-42$, esp. 211. 
By de-contextualising Anselm's argument, Richard established a precedent which later allowed early Franciscans to attribute something like Avicenna's argument to Anselm, albeit without acknowledgement, in what was ultimately an argument of their own invention. This Franciscan version of the argument is the one to which Thomas Aquinas likely, and famously, objected, in objecting to what he referred to as Anselm's argument. At the same time, this rendition of the argument is closer to the one that is associated with Anselm's legacy to this day. Through the Summa Halensis and its authors, consequently, it is fair to say that the West was introduced for the first time in intellectual history to what has come to be known as Anselm's ontological argument.

\section{Reading Anselm's Argument}

In recent years, a growing body of literature has cast doubt on the notion that Anselm offered nothing but an ontological argument for God's existence such as we understand it today, whether to foster faith seeking understanding in believers or to persuade non-believers to believe. While this is not the place to explore that literature in full, I do want to consider some textual evidence which supports an alternative reading, starting with the argument from Chapter 2 itself, which can be stated as follows: ${ }^{5}$

God is a being than which nothing greater can be conceived (i.e. the supreme being).

It is better to exist in reality than in the mind alone.

God is whatever it is best to be.

Therefore, God exists in reality as well as in the mind.

In formulating this argument, Anselm asserts unequivocally that all who apprehend the definition of God as supreme being must affirm that he exists. After all, God is whatever it is best to be, and existence in reality is better than existence in the mind, rather like the existence of wealth is superior to the mere thought of possessing it. On this basis, Anselm goes on to argue in Chapter 3 that those who apprehend the meaning of the word 'God' cannot logically deny that he exists. As Chapter 4 elaborates, it is only possible for the fool to say in his heart, 'there is no God', insofar as it is possible in principle to think a thought that does not bear on reality.

So construed, Anselm's argument could in fact be construed as an ontological proof for God's existence. The fact that his own detractor Gaunilo interpreted it as such suggests that it was indeed ripe for consideration in this way, and Anselm's reply to Gaunilo indicates that he was aware of and accepted that. Nevertheless, the broader context of the Proslogion summons us to read the proof in a different light. The text begins with a prayer in which Anselm professes his inability to

5 Lydia Schumacher, 'The Lost Legacy of Anselm's Argument: Rethinking the Purpose of Proofs for the Existence of God,' Modern Theology 27 (2011): 87-101. 
know God and pleads with God to restore in him the image of God that is effaced by $\sin ^{6}$ When referring to this process of renewal at later points in the text, Anselm notably continues to operate on the assumption that God himself remains altogether unknowable, insofar as the divine nature exceeds the spatio-temporal constraints of human knowledge. ${ }^{7}$

Thus, the restoration Anselm has in mind does not reinstate knowledge of God in his own right but an ability to reflect the image of a God who never ceases to know himself as highest good, in the only context possible for human beings, namely, that of ordinary knowledge and life. What is restored, in other words, is an ability to think and act in reality in keeping with the belief in God as 'highest good' that is held in the mind. The exercise of such an ability has a highly significant effect when it comes to assessing objects and circumstances in the world. For the knowledge that God alone is absolutely significant prevents persons from ascribing too much significance to these matters and thus from perceiving them in ways that are inconsistent with reality, and a personal ability to flourish therein. In sum, the knowledge of God checks the human tendency to engage in the sinful patterns of thinking and acting whereby the image of God is effaced. By the same token, it replaces them with patterns of appreciating things for what they really are, as God made them to be. ${ }^{8}$

In that sense, the knowledge of God that Anselm perceives as realistically attainable is a knowledge of things other than God, assessed in the light of faith in his absolute significance. By Anselm's account, this 'mediated' knowledge of God can only be gained progressively, as the eyes of the mind gradually re-adjust to the vision of the world in God's light, just as physical eyes must become accustomed to brighter levels of light. ${ }^{9}$ So conceived, Anselm's argument is ultimately a resource for bringing a professed belief in God to bear in reality, and thereby for cultivating a habit of seeing the world in the light of faith. In doing this, believers gradually conform to the image of a God who always thinks and acts in the knowledge of his supreme goodness. ${ }^{10}$ At the same time, Anselm concludes in the final chapters of the Proslogion that they become ready to gaze upon the reality of God himself in the life to come. ${ }^{11}$

This 'pedagogical' way of interpreting Anselm's argument as a 'formula' of sorts for applying belief in God is borne out by many passages in the wider text of the Proslogion that tend to be neglected on the standard reading. In Chapter 2 itself, for ex-

6 Anselm of Canterbury, Proslogion, prol., in S. Anselmi Cantuariensis Archiepiscopi Opera Omnia, 2 vols, ed. Franciscus Salesius Schmitt (Stuttgart-Bad-Cannstatt: Friedrich Frommann Verlag, 1968). 7 Anselm of Canterbury, Proslogion 1, 13, 16.

8 See compatible readings of Anselm in Matthews, Reason, Community, and Religious Tradition, 1-14; Schumacher, 'The Lost Legacy of Anselm's Argument,' 87-101; Robert Sokolowski, The God of Faith and Reason: Foundations of Christian Theology (Washington, DC: The Catholic University of America Press, 1995), 1-11.

9 Anselm of Canterbury, Proslogion 26.

10 Anselm of Canterbury, Proslogion 13-21.

11 Anselm of Canterbury, Proslogion 24-6. 
ample, Anselm provides an illustration as to how his argument is meant to function. More specifically, he notes that,

when a painter plans beforehand what he is going to execute, he has the picture in his mind, but he does not yet think that it actually exists, because he has not yet executed it. However, when he has actually painted it, then he both has it in his mind and understands that it exists because he has now made it.

As a mental picture provides a painter with the resource needed to transform that picture into a reality, so this illustration confirms that Anselm's argument is a tool that for allowing belief in God to form and transform ordinary thoughts and actions.

In keeping with the ancient tradition of spiritual exercises, consequently, Anselm seemingly delineates a sort of 'practical syllogism' through which we may apply the belief that that God is 'whatever it is best to be' in assessing the worth of objects and circumstances we encounter in the world. By these means, we ensure that God does not merely exist notionally in the mind but also plays a vivid part in our dealings with reality. This is arguably what Anselm has in mind when he claims that 'existence in reality is better than mere existence in the mind', namely, that it is better to operate in reality like God exists than simply to say that one believes that he does, and act as if he does not.

While it is clearly foolish on Anselm's view to deny that God exists altogether, it is likewise foolish nominally to acknowledge his reality as the supreme being and then fail to live in accordance with what is professed to be true. In short, it is foolish because it is inconsistent and thus irrational, not to say hypocritical. So construed, Anselm's argument provides a remedy against hypocrisy because it facilitates an increase in the consistency between the belief Christians profess or hold in the mind about who God is as the sole being of absolute significance and the way they live in reality. Insofar as its application reveals the difference belief in God makes to the way we understand everything that is not God, it may be said to provide a sort of 'personal proof' for the reality of God. To make both believers and through them, unbelievers aware of this difference is arguably what Anselm's project of faith seeking understanding is all about.

\section{The Sources of the Summa's Proof}

Although Anselm's argument thus interpreted is not wholly lacking in potential to reinforce belief in the reality of God, a reading of his whole Proslogion refutes the notion that it does nothing but deliver the sort of ontological proof for God's existence that it has long been supposed to provide. How then did such a reading of his thought emerge? To answer this question, we must look not only to the sources of early Franciscan thinkers, who were the first in the West not only to incorporate Anselm but also to defend a so-called proof for a necessary existent. As noted in the 
chapter on philosophical context, this proof was one of Avicenna's most celebrated contributions to the history of philosophy. In what follows, I will review briefly the contours of Avicenna's argument, before examining the proof for the necessary existence of one God, whereby Richard of St Victor paved the way for the Franciscan appropriation of Avicenna.

The proof for the necessary existent that Avicenna presents in his Book of the Cure, which is the text that Latin scholars at this time would have known, starts from encounters with possible or 'contingent beings'. These are beings that did not have to exist, and which cannot therefore be the source of their own existence, goodness, truth, or whatever. The existence of such beings suggests that there is a further being through whom they exist, which is itself the cause of its own existence and which is necessary in that sense. In Avicenna's account, this proof engenders the further conclusion that there cannot be an infinite chain of beings that cause one another, but that there must be an initial, uncaused cause at which they all terminate.

Though reflection on things possible in themselves and necessary through another serves as the catalyst for concluding that there is a necessary existent, Avicenna insists that his is not a cosmological argument that infers the necessary existent from empirical realities. ${ }^{12}$ Rather, it is a purely metaphysical proof which can be worked out simply through rational reflection on what it means to be a necessary being that exists through itself and through which other things have their existence. Such a being cannot not exist, insofar as it is part of its definition to cause its own existence. Since we are innately aware of what it means to be a necessary being, moreover, we cannot fail to know this being not only as the cause of itself but also of everything else.

On this showing, contingent beings do not so much prove the reality of God as trigger the latent awareness of the one through whom they have their existence, who in turn exists through himself. ${ }^{13}$ That stated, it is a matter for debate whether and to what extent an Avicennian proof has something in common with ontological arguments let alone the one attributed to Anselm. While both arguments move from the definition of God to his reality, this only establishes them as members of the same species or genre, not as argumentative twins. ${ }^{14}$ Those who specialise in Avicen-

12 Avicenna, Metaphysics 1.3, in Avicenna Latinus: Liber de Philosophia Prima sive Scientia Divina, 3 vols, ed. Simone Van Riet (Leiden: Brill, 1977-83), 1. See also the translation work by Michael E. Marmura, The Metaphysics of the Healing: A Parallel English-Arabic text = al-Ilahīyāt min al-Shifä' (Provo: Brigham Young University Press, 2005).

13 Pegis, 'The Bonaventurian Way to God,' 216, quoting Étienne Gilson, La philosophie de saint Bonaventure, 2nd ed. (Paris: Vrin, 1943), 108: 'All knowledge comes from prior knowledge, and the apparently immediate and primitive recognition of the contingent supposes the prior knowledge of the necessary. Now the necessary is nothing other than God; human intelligence, therefore, experiences the fact that it already possesses the knowledge of the first being at the very moment when it undertakes to prove it.'

14 Peter Adamson, 'From the Necessary Existent to God,' in Interpreting Avicenna: Critical Essays, ed. Peter Adamson (Cambridge: Cambridge University Press, 2013), 170: 'proving the existence of a nec- 
na will be better placed to address this debate, which is not the primary focus here. The main goal in the present context is instead to trace how early Franciscans came to project Avicenna's proof for the necessary existent on to Anselm.

For this purpose, we must turn to the argument for the necessary existence of one God that Richard of St Victor offers in the first chapter of his De Trinitate, the overarching project of which is to establish the necessity of God's unity and ultimately Trinity. One of the key assumptions underlying Richard's project is that 'we do not hold anything more firmly than that which we grasp by a resolute faith' ${ }^{15}$ Although this assumption may seem counter-intuitive, since God subsists beyond the reach of human experience, Richard seems to think it holds true in an objective sense, insofar as God is the source of all beings, and thus the only being that must exist.

Since 'it seems utterly impossible that things that are necessary lack of a necessary reason', Richard further argues, there must be not only plausible but also necessary reasons for the things we believe about God. ${ }^{16}$ Here, he borrows a distinction between 'necessary' and 'fitting' reasons that Anselm had invoked in explaining why God became man, and which notably does not feature in his Proslogion. In the context where Richard deploys such reasons, the belief at issue is the oneness of Godand the corresponding impossibility of positing more than one God. Richard's argument for divine unity turns on a preceding argument in favour of divine necessity.

In this regard, Richard notes that everything that exists must either exist from eternity or in time and must receive its being out of another or from itself. On this basis, he concludes that a being, such as God, that is from eternity must also be from itself, because nothing that is eternal is preceded by and thus derived from another. By contrast, creatures which exist in time necessarily come from God rather than from themselves. ${ }^{17}$ Precisely because God is a being who derives from no other, Richard further argues, there cannot be more than one God, otherwise there would be multiple beings that do not come from another. However, the sheer existence of multiple beings would suggest that one came from the other, which entails a contradiction. ${ }^{18}$

Although Richard does not quote the Proslogion or any other source explicitly in developing these arguments-a practice quite common in this type of writing and also used by Anselm-he makes implicit reference to Anselm in affirming that 'it is essential that something supreme should exist', and 'we define as supreme over all things, that of which nothing is greater, nothing is better. Without a doubt, the rational nature is better than the reasonless nature. It is indispensable, then, that

essary existent is different from proving the existence of God,' and neither Avicenna nor the Franciscans seemingly intend to do the latter.

15 Richard of St Victor, De Trinitate 1.2, in De Trinitate: texte critique avec introduction, notes et tables, ed. Jean Ribaillier (Paris: Vrin, 1958).

16 Richard of St Victor, De Trinitate 4.

17 Richard of St Victor, De Trinitate 7.

18 Richard of St Victor, De Trinitate 17. 
a rational substance be supreme above everything. ${ }^{19}$ As he later posits, 'divine knowledge cannot conceive anything on the intellectual plane more perfect than God. Even less, then, human understanding can imagine something greater and better than God.'20

In this context, it seems clear that Richard imports the main claims Anselm makes in Chapter 2 of his Proslogion into his own argument for the necessary existence of a singular being that is 'from itself' and is, as such, from eternity. By the same token, Richard removes Anselm's argument from the broader context of the Proslogion, jettisoning the rest of the 26-chapter text in what has now become a relatively common practice. In doing so, he set the stage for the Halensian Summists to go a step further and deploy Anselm's argument not merely to defend a proof for the necessary existence of one God but the necessary existence of God in himself, along the lines of Avicenna. The justification for this conflation was already seemingly provided by Richard when he invoked Anselm's 'necessary reasons' to argue that there is only one God. In what follows, we will see how the Summa brings its sources together while moving beyond them in an innovative way.

\section{The Proof for a Necessary Existent}

The very first question addressed in the Summa Halensis, after introductory material on the status of theology as a science and the nature of knowledge of God, inquires whether God exists necessarily, or is a necessary existent. The very fact that this question, not previously posed in a scholastic text in this same way, is posed here is quite striking. It is hard to imagine that the question could have occurred to the Franciscans in a vacuum: they found it in their inheritance of Avicenna. The Summa's answer to this question is itself delivered across two main sections of the text. The first argues that the divine substance exists by necessity (quod necesse est divinam substantiam esse). The second contends that God cannot be thought not to exist (quod non potest cogitari Deum non esse). As a matter of fact, however, the first article presents five main arguments why God necessarily exists.

Although most readers today tend to associate the idea of delineating 'five ways' to prove God's existence with Thomas Aquinas, the Summa Halensis was the first text to implement this approach, with arguments taken from the notions of being, causality, truth, goodness, and eminence..$^{21}$ The first way of proving the necessary existence of God, from being or existence, is elucidated with reference to arguments from Ri-

19 Richard of St Victor, De Trinitate 11.

20 Richard of St Victor, De Trinitate 19.

21 Alexander of Hales, Doctoris irrefragabilis Alexandri de Hales Ordinis minorum Summa theologica (SH), 4 vols (Quaracchi: Collegium S. Bonaventurae, 1924-48), Vol I, P1, In1, Tr1, Q1, C1 (n. 25), I-V, pp. 40-2; Lydia Schumacher, 'Aquinas's Five Ways: A Pastoral Interpretation,' Theology 119 (2016): $26-33$. 
chard of St Victor, largely rehearsed above, which assert that all things that are or could be either existed from eternity or began to be in time, and have their being either from themselves, or from another that exists of its own accord. ${ }^{22}$

On this basis, Richard distinguishes between four different ways in which a being can exist, namely, from eternity and from itself; neither from eternity nor from itself; from eternity, but not from itself; or from itself but not from eternity. According to Richard, the last option is impossible: nothing is able to exist from itself and not from eternity, else there would have been nothing to bring into existence all that began to exist and continues to exist in time. By the same token, something had to exist from eternity and from itself to give existence to other things. In the account of the Summist, this 'something' is the divine substance.

The second, closely related, way to prove the necessity of the divine, namely, from causality, takes an insight from John of Damascus as its point of departure. According to John, all that exists is either caused or uncaused, that is, created or uncreated. But all that is causable is changeable; that is to say, it moves from non-being into being. But nothing can cause itself. Therefore, there must be an uncaused substance, namely, God.

The third way, concerning truth, refers primarily to Anselm's De Veritate. There, Anselm writes that if truth had a beginning or an end, then even before it began to be true, it would have been true that truth did not exist at some point in time. After truth comes to an end, moreover, he writes that it will be true that 'there is no truth'. Since truth cannot therefore exist or even cease to exist unless there is truth, truth exists eternally, and the truth is God.

The fourth way, from goodness, turns specifically to Anselm's most famous rendering of his argument in Proslogion 2, in order to affirm him as the supreme good that is the source of all goods. As such a good 'than which nothing greater can be conceived', he exists not only in the mind but also in reality, because existence in reality is better than mere existence in the mind, and God is whatever it is best to be. Only such a good can give rise to others. In elaborating this interpretation, fascinatingly, the Summa acknowledges that its reading of Anselm is not based directly on his main text, but is to some extent eked out of his reply to Gaunilo. There is as clear an admission as one could hope for that the Summa's understanding of Anselm was not necessary the primary one that Anselm intended.

The fifth way, from eminence, draws on Anselm's Monologion 4, with a corroborating quotation from Richard of St Victor, which calls attention to the fact that there are degrees of being, in which higher grades of being serve as causes for those that are lower. As the Summa observes, these causes cannot regress infinitely but must terminate in an ultimate cause. On this basis, the Summist concludes with Anselm that there is a super-eminent being, which is superior to all other natures, and is ranked inferior to none. And this is God.

22 SH I, P1, In1, Tr1, Q1, C1 (n. 25), I, p. 40, quoting Richard of St Victor, De Trinitate 1.6. 
In summary, there are five ways to establish the necessity of the divine being. The first does so by appealing to the necessity of an eternal being that can give rise to temporal beings; the second, to something uncaused and unchanging that can engender things that are caused and changing; the third, to an eternal truth that is the condition of possibility for all finite truths, even the truth that truth may begin or end; the fourth, to a good that is the source of all goods; and the fifth, to the necessity of a super-eminent being that supersedes all grades of finite being.

At face value, these five ways might seem like cosmological ways of the sort provided by Thomas Aquinas. After all, they infer the existence of God on the basis of empirical things that are temporal, caused, true, good, and exist at inferior grades of being. In the second article of the Summa's discussion, however, it becomes clear that such a bottom-up approach to establishing the divine reality is not what the Summists have in mind. Here, the Summa follows the precedent set by Richard of St Victor in his De Trinitate to remove Anselm's argument from the broader context of the Proslogion. For his part, we have seen, Richard deployed this argument to argue for the necessity of one God.

In the Franciscan account, by contrast, the argument for divine necessity becomes an end in its own right. That is not to suggest that the Summists actually entertain doubts about God's existence. This would have been highly unlikely at the time. Rather, they seek to give a reasoned explanation for the belief in God that they take to be true. This explanation turns on the assumption that our knowledge of God is prior to that of anything else: we possess it before we even encounter things in the world. This is because the human mind is the image of God and is, as such, 'naturally directed...toward that being in whose image it exists'. ${ }^{23}$ As Anton Pegis has noted, this is a very strong interpretation of what John of Damascus meant when he insisted that all human beings enjoy an innate knowledge of God, namely, that if God is the light of reason, we cannot help but know God.

For these Franciscans, God's image is the locus of our capacity not only to know God himself but also to know all the things in the world that he has made. We cannot know the world before we know him because we have no recourse to true understanding of reality without aid from the one who made it. At the background here is the doctrine of the innate knowledge of the transcendentals which the Summa also adapts from Avicenna. According to the Franciscan version of this doctrine, we have an innate knowledge of being and its first determinations, which makes it possible for us to comprehend beings accurately in their own right and thereby in terms of the way they reflect their creator.

When we reflect on God as the very source of such cognitive powers, or on ourselves as his images, consequently, we cannot help but know him as necessarily existent. We alight upon a proof for God's existence that is purely rational or based solely upon sources derived from the human mind itself. These are the very resources

23 Pegis, 'The Bonaventurian Way to God,' 225. 
through which we can draw the further inference that God must exist on his own terms. As he is the source of our being, the Summa reasons, he must likewise be the source of his own. In confirming this, the Summa restates Anselm's argument as follows: God is whatever it is best to be; that than which no better can be conceived; the supreme being. Since existence in reality is better than existence in the mind or imagination only, God necessarily exists.

This conclusion does not apply to any being other than God, the Summa echoes Anselm's reply to Gaunilo in affirming, insofar as beings besides God have a beginning and end in time and can therefore in principle be thought not to exist. ${ }^{24}$ While it is possible for this reason to think of such beings in abstraction from the question whether they actually exist, God cannot be regarded as non-existing, precisely because the definition of his being is to exist through himself, or to exist necessarily, and so to be one through whom other beings exist, insofar as they do so.

Once God has been established as self-subsistent along these lines, he can be further recognized as the one through whom all other things exist, are good, and so forth, with the help of the five ways. We can see God as the Supreme Being that is reflected in created beings; the Cause of what is caused; the Good that is in ordinary goods, the supreme Truth that is in truths, and so on. The innate knowledge of God which we access either through reflection on ourselves or himself is the key to discovering his presence in the world, albeit finitely, but in a nonetheless direct or univocal way as we will discover in the next chapter.

In the aforementioned respects, we can discern how creatures testify to his reality, not so much by establishing it on empirical grounds as by triggering the awareness of him that is always present in the mind as his image. As Étienne Gilson put it, the proofs from creatures are proofs on this understanding because 'they set in motion intelligible notions that imply the existence of God'. ${ }^{25}$ Thus, he goes on to say, 'it is only in appearance that our reasoning takes its origin in the recognition of sensible data'. ${ }^{26}$ Since we have an innate idea of God, the 'sensible world will never aid us in constructing it; it can only offer us the occasion to recover it. ${ }^{27}$

So construed, the five ways are clearly founded on one purely rational or ontological way of proving God's existence. This can itself take two forms, depending on whether we reflect on God in his image or in terms of who he is in himself. In affirming this, incidentally, the Summa anticipates Bonaventure's three-pronged approach to proving God's existence on the basis of God's interior image, the world, or the very

24 SH I, P1, In1, Tr1, Q1, C2, Ar2 (n. 27), Solutio, pp. 44-5.

25 Pegis, 'The Bonaventurian Way to God,' 216, quoting Gilson, La philosophie de saint Bonaventure, 108.

26 Pegis, 'The Bonaventurian Way to God,' 216, quoting Gilson, La philosophie de saint Bonaventure, 108.

27 Pegis, 'The Bonaventurian Way to God,' 216, quoting Gilson, La philosophie de saint Bonaventure, 108. 
definition of God: what is inside, outside, or above the self. ${ }^{28}$ As we have seen, all these ways are founded on the innate knowledge of God as the one through whom we ourselves possess our characteristic powers: who is closer to us than we are to ourselves and is therefore not unknowable by us. This knowledge in turn enables us to see that he exists in himself-his essence is his existence, as scholastics put it-and that he is as such the giver or existence to all things which testify to his reality in turn.

There is only one way we can fail to recognise God's existence in any of the aforementioned ways. In illustrating this point, the Summa distinguishes between knowledge insofar as it pertains to the knower versus the object known. In his own right, as the object known, God cannot be thought not to exist. To understand the meaning of the word 'God' is after all to understand that he cannot not exist: that the perfection of existence is part of what it means for him to be the supreme and self-subsistent being through whom all other beings have their being.

As knowers, however, we may refuse to acknowledge that we subsist through one that it self-subsistent: that the divine being is the very condition for our existence. In denying this, we inevitably become ignorant of the testimony to God's existence that derives not only from the self as his image but also from creatures and from reflection on the very meaning of the term 'God', which entails existence by definition. ${ }^{29}$ According to the Summa, this is what Anselm means when he allows that the fool may say in their heart, 'there is no God': not that God can be objectively regarded as non-existent, but that we can refuse to accept his place in our lives, as the source of our life, our powers, and of all things.

This is what is at stake in a further distinction the Summa draws between understanding of a thing in universal or particular terms, or in terms of its universal but not its proper reason. As the Summa notes, many individuals understand that beatitude is happiness. While they therefore understand what beatitude is in universal terms, they may still believe that it specifically consists in wealth, honor, or other worldly goods. Thus, they may fail to appreciate what beatitude is in proper terms, and so to grasp that it turns on the vision of God. By the same token, idolaters recognize God in universal terms, as the principal and omnipotent being, but overlook what he is in proper or specific terms, elevating false images or false gods as objects of worship. In this way, they give to something that is not God a place that he alone should have in our lives.

The only way to overcome the ignorance of him that results is through repentance from sin, which restores recourse to the innate knowledge of God through which we can know that he exists in the three main ways. When we accept that he alone can satisfy the conditions for our own and all possible forms of existence, as a matter of fact, we cannot actually avoid acknowledging that God is self-subsis-

28 Pegis, 'The Bonaventurian Way to God,' 206-42, esp. 210.

29 SH I, P1, In1, Tr1, Q1, C2, Ar1 (n. 27), Solutio, pp. 43-4. 
tent, and, as such, necessarily exists. As we have seen, the basic argument that underlies this conclusion is similar to that of Avicenna: it starts from the innate assumption that all things that exist, including the self itself, must do so through a being that exists through itself and is necessary in that sense.

In order to draw this type of argument into the Christian tradition of thought, the Summists project something like Avicenna's proof for a necessary existent on to Anselm by removing Chapter 2, not to mention 3 and 4, of the Proslogion from its larger context. In this regard, they followed the example of Richard of St Victor, who had done something similar previously in order to establish that there is necessarily only one God. The further de-contextualisation of Anselm's discussion of 'necessary reasons' to support this conclusion arguably lay the groundwork for the Summists later to read Avicenna's proof into a text by Anselm that simply does not contain anything exactly like it.

Although the Summa is indebted to such sources, its proof for God's necessary existence is clearly more than the sum or function of them. As in other cases of scholastic thought, the Summists worked with their own objectives in mind and turned their sources precisely to that end. What they produce as a result is an argument the exact form of which cannot be found in any of the authorities they employ, including Anselm. That is not to suggest that the Summists or even Richard mishandled Anselm's writings or any others in recasting their meaning. As we have seen, the manipulation of sources was standard and even required practice at a time when the accepted way of thinking creatively and innovatively involved locating personal opinions within larger, if loosely defined traditions or streams of thought, elaborating and even redefining them in the process.

In the case of the first Franciscans, this is precisely what happened with Anselm's Proslogion. By excising Chapter 2 from this text and recasting it as a proof for the necessary existent, the Summists bequeathed to subsequent thinkers an understanding of Anselm that has dominated in some capacity ever since. As far as the Western tradition is concerned, consequently, the Franciscans, not Anselm, must be regarded as the real innovators of Anselm's ontological argument. In closing, therefore, it is worth considering exactly what may have motivated the early Franciscans as Franciscans to articulate a theistic proof in this novel manner.

\section{The Franciscan Nature of the Proof}

Although the authors of the Summa do not elaborate explicitly on the motivation for their work, it stands to reason that their intent was at least in part to articulate philosophical and theological positions that were consistent with the spiritual ideals of the order's founder, Francis of Assisi. This would have been necessary for survival in their institutional home at the University of Paris. Furthermore, it was essential to training up the next generation of Franciscans in a distinctly Franciscan way of thinking. This generation included the likes of Bonaventure, who claims to have 
learned all his good ideas from his Parisian Franciscan teachers, first and foremost, Alexander of Hales.

For these founders of the Franciscan school of thought, Avicenna's argument was not only conveniently accessible, but also particularly well suited to capturing the example of Francis of Assisi. Famously, the saint maintained a constant consciousness of God's presence that gave him insight into the way all creatures testify to their Creator. In a description of the Franciscan argument, Scott Matthews affirms that 'it is this teaching above all that fundamentally expresses Francis' experience of God, as immanent within the nature and intimately related to the soul. ${ }^{30}$

According to the Franciscan tradition of thought, we have seen that the ability to know God in these ways can never be lost, even in the wake of sin, lest God be charged with failing to render himself eminently knowable to all human beings. By this account, consequently, sin simply makes us ignorant of the knowledge of God we nonetheless always possess. As such, it is a defect of the will to exhibit the love of God that opens up access to the knowledge of God, not a defect on the part of the intellect as regards the knowledge of God himself. By leading us to love things other than God more than God, in summary, sin obscures our intuitive awareness of God.

For the early Franciscans, this awareness of God can only be restored through the rekindling of the will to love God and thereby to regain immediate access to the innate knowledge of him that was never lost. In addition to explaining and holding Franciscans accountable to maintain the intuitive, personal connection with God that Francis enjoyed, this way of putting things may have been designed to assert the legitimacy and even primacy of Franciscan thought at a time when the very idea of a Franciscan intellectual tradition was being called into question both within and outside the order, by those who believed intellectual pursuits to be incompatible with Francis' intentions for his followers.

By positing love-and undoubtedly a Franciscan understanding of it-as the 'key' to knowledge not only of God but also, through him, of everything else, the Summists implicitly declared that a Franciscan attitude, and even a Franciscan lifestyle, is the means to all true knowledge, of the world, the self, or God. In turn, they suggested that such knowledge is constitutive of the Franciscan perspective and Franciscan lifestyle. ${ }^{31}$ In this way, they refuted objections to a Franciscan intellectual tradition at the level of that tradition's own development. By the same token, the Summists codified an approach to natural theology that would become a fixture not only in the later Franciscan intellectual tradition but even, arguably, in modernity.

30 Matthews, Reason, Community, and Religious Tradition, 53.

31 Matthews, Reason, Community, and Religious Tradition, 71-3. 